\title{
De ballingschap van de Byzantijnse tekst ${ }^{1}$
}

Jakob van Bruggen

Departement Nieuwe Testament

Theologische Universiteit van de Gereformeerde Kerken (Vrijgemaakt)

KAMPEN

Nederland

\begin{abstract}
For more than a century the Byzantine Text-type has been in exile. Meanwhile, endeavours to re-establish the original text of the New Testament have not succeeded. The question thus arises whether it is necessary to keep the banished text silent forever. This article describes the revival of a plea for listening also to the Byzantine Text-type in restoring the ancient text. Arguments against this text in exile are evaluated. Two points in favour of the banished text are introduced: 1. Its readings are nearly always supported by one or more of the other text-types: why should the accomplices go scot-free? 2. Its readings have more than once the flavour of authenticity: why should we leave innocent readings in exile?
\end{abstract}

\section{Inleiding}

In dit artikel over de Griekse tekst van het Nieuwe Testament wil ik tegen de achtergrond van de huidige tekstkritiek aandacht vragen voor de positie van het Byzantijnse teksttype. De periode van meer dan een eeuw die sinds 1881 achter ons ligt, wordt gemarkeerd door een afkeer van dit type. Er kwam als het ware een bevrijdingsbeweging op gang: de oude tekst moest worden bevrijd van de kluisters van de Byzantijnse liegemonie. Tot welk resultaat heeft dit geleid? Hoe is het verder te verklaren dat er nog steeds mensen zijn die aandacht geven aan de reeds meer dan een eeuw verbannen Byzantijnse tekst? Is dit een hardnekkig anachronisme tegen de stroom van tijd en wetenschap in of verdienen deze stemmen meer aandacht?

1 In Mei 1993 het prof Van Bruggen 'n recks gaskolleges in Suid-Afrika aangebiod Een van hierdic lesings het gehandel oor dic teks van dic Nuwe Testament in Geuysigde vorm van dic lesing word nou in artikelvorm gepubliseer. (Rodaksie - In die Sknnıg) 


\section{Balans van een bevrijdingsbeweging}

Wanneer wij de balans van meer dan een eeuw bevrijdingsbeweging opmaken, zijn er positieve dingen te melden.

In de eerste plaats is het materiaal van de handschriften toegankelijker dan ooit. Specialistische studies uit het Institut te Münster en van de hand van Metzger verrijken onze bibliotheken. Ook komen uitgaven vrij waarin vrijwel het gehele varianten-bestand bij een bijbelboek kan worden nagetrokken. Het IGNTP gaf Lucas uit in twee delen (1984-1987) en het Münster-institut verzorgde de katholieke brieven (1987) alsmede de brieven van Paulus en Hebreeën (1991).

In de tweede plaats wordt de niet-specialist uitstekend voorzien van overzichtelijke handboeken die hem binnenleiden in de laatste stand van materiaal en theorie. In Duitsland hebben we Der Text des Neuen Testaments van Kurt en Barbara Aland (1982) en in het Dietse taalgebied Die teks van die Nuwe Testament van de hand van Kobus Petzer (1990). In het Engelse taalgebied werd het bekende boek van Bruce M. Metzger The Text of the New Testament in 1992 opnieuw uitgegeven met een uitvoerig appendix over de periode 1964-1990.

In de derde plaats is de bekende Nestle-editie in haar 26 ste druk voorzien van zoveel nauwkeurig aangeduide varianten en zulke nuttige appendices, dat deze editie in rijkdom aan materiaal alle vorige ver achter zich laat.

Deze grote toename van materiaal en deskundigheid gaat echter niet gepaard met meer zekerheid over de juiste Griekse tekst. Op dit punt is er eigenlijk alleen maar achteruitgang. Was Hort vast overtuigd van de neutraliteit van de B-tekst, inmiddels deelt bijna niemand meer die gedachte. De zoektocht blijkt ingewikkelder dan werd gedacht.

Zo heeft Aland de merkwaardige term lokal-genealogisch bedacht - duidelijk een verlegenheidsterm. Zij geeft aan dat de genealogie van de handschriften (waarop Hort sterk steunde) ontoereikend is en dat gekozen moet worden voor een eclectische tekstvaststelling per variant. Daarbij domineert dan de genealogie van de variant, maar die genealogie kan alleen worden vastgesteld door ook de taxatie van handschriften erbij te betrekken. Aland wil zeker geen streng eclecticisme zoals Kilpatrick en sommige Nederlandse tekstkritici nastreven. Dit zou immers kunnen betekenen dat in een aantal gevallen zomaar varianten uit de Egyptische tekst komen te vervallen en die uit de Byzantijnse tekst gekozen worden, terwijl toch volgens Aland de Egyptische tekst genealogisch goed is en de Byzantijnse pervers. In feite hinkt Aland dus op twee gedachten: enerzijds genealogie van handschriften, maar anderzijds vaststelling van de tekst per lezing. Deze mixtuur illustreert het echec van de methode van Hort. 
Terwijl Hort de moed had om in zijn eentje een tekst vast te stellen die hij original noemde, zijn we momenteel niet verder dan een compromis-tekst van vijf geleerden. Na de tweede wereldoorlog leefde de hoop dat Aland een nieuwe wetenschappelijke tekst zou vaststellen. Dat ideaal is geleidelijk aan verdwenen. In de plaats ervan kwam een UBS-tekst, vastgesteld door een comité met meerderheid van stemmen. De meerderheidstekst van duizenden handschriften bleef in ballingschap en in de plaats daarvan kwam een meerderheidstekst van vier à vijf tekstkritici (die dikwijls met een twee tegenover drie stemming een tekst vaststelden die als geheel zó in geen enkel handschrift voorkomt!). Deze tekst werd uiteindelijk ook de basis voor Nestle-Aland. Het project van de zoektocht naar een betere tekst is feitelijk mislukt, hoe mooi de editie Nestle-26 ook is opgetuigd.

Een voorbeeld voor de inpasse is Lucas 23:34a (Jezus' bede om vergeving voor de soldaten bij het kruis). De balans van de argumenten blijkt wanneer Radl (1988) dit versdeel voor $e c h t$ verklaart (het is weggelaten vanwege een verkilling tegenover de Joden) en Petzer (1991) het als onecht beschouwt (het is juist later ingevoegd om het toenemend anti-judaisme tegen te gaan).

Nu was het grote startpunt in 1881: de minderwaardigheid van de Byzantijnse tekst. Dit is het nog steeds voor de meesten. Het is echter opvallend dat na meer dan 100 jaar verbanning van dit teksttype er nog altijd geen nieuwe tekst is gevonden.

Sommige bijbelkritische theologen hebben hier een verklaring voor. Volgens hen was er oorspronkelijk geen vaste tekst, maar slechts een aantal traditiestromingen, waaruit geleidelijk een soort tekst is uitgekristalliseerd. Die kerkelijke tekst is eigenlijk de oudste tekst, maar zij is secundair ten opzichte van de divergerende gemeentetradities uit de eerste twee eeuwen. Deze verklaring neem ik niet over: zij past niet bij de feiten van de tekstaanvaarding bij de apostolische vaders, Irenaeus en Tertullianus.

Wel ben ik van mening dat een verklaring gezocht moet worden voor het feit dat de moderne tekstkritiek in een wat uitzichtloze draaikolk is beland. Loopt de weg soms dood in een moeras wanneer men de Byzantijnse tekst verbant?

\section{Herleefde aandacht voor een verbannen tekst}

In de zeventiger- en tachtigerjaren van deze eeuw klinkt weer krachtiger het pleidooi voor de oude tekst die in de kerk gedurende vele eeuwen is gelezen: het Byzantijnse type. Een duidelijk symptoom daarvan is de verschijning van The Greek New Testament According to the Majority Text (edited by Zane C. Hodges and Arthur L. Farstad - 1982). 
Hoewel dit pleidooi voor de Byzantijnse tekst dicht in de buurt komt van het vasthouden aan de $17 \mathrm{de}$-eeuwse textus receptus, is het daarvan toch principieel en methodisch te onderscheiden. De pleitbezorgers voor die textus receptus zijn voomamelijk te vinden in de kringen van hen die de oude reformatorische vertalingen in ere willen houden. Hun actie richt zich tégen de nieuwere Griekse tekst die aan moderne vertalingen ten grondslag ligt: het alternatief is dan als vanzelf de oudere vertaling én de daaraan verbonden textus receptus. In Engeland maakt het Trinitarian Bible Society zich sterk voor de Authorized Version (1611). De Gereformeerde Bijbelstichting in Nederland is een parallel verschijnsel ten bate van de Statenvertaling (1637). In de Engelssprekende wereld is de bewustheid voor de samenhang van nieuwere vertalingen en een andere Griekse grondtekst bij het kerkvolk veel sterker dan in Nederland. Dit is te danken aan een regel die de makers van de Revised Version (1881) meekregen:

That the Text to be adopted be that for which the evidence is decidedly preponderating; and that when the Text so adopted differs from that from which the Authorised Version was made, the alteration be indicated in the margin (regel 4).

Het gevolg van deze regel was dat iedere bijbellezer de wijzigingen op de voet kon volgen, terwijl zij in de Nederlandse Nieuwe Vertaling (1951) meestal onopgemerkt blijven. Tot vandaag toe weten vele niet-theologen in de zuidelijke staten van de Verenigde Staten heel goed dat er iets aan de hand is met de tekst van het Nieuwe Testament en het lijkt hun toe dat 'de wetenschap' hier het 'oude woord van God' wil aantasten of verminken. Hun agressie tegen de WestcottHort tekst is soms religieus geladen en doet meer dan eens, vanwege beperkte kennis van de tekstkritiek, wat ridicuul aan. Ook hun woordvoerders (Fuller, 1971; Letis, 1989) ontkomen in meerdere of mindere mate niet aan gezichtsverenging doordat zij teveel de tekst vanuit de vertaling benaderen.

Sommige woordvoerders weten echter tot een zekere zelfstandigheid ten opzichte van de traditie te komen en bij hen klinkt dan veel door van de kritiek die ten tijde van Westcott-Hort door deskundigen is geuit.

Het is namelijk werkelijk niet zo dat iedere deskundige in 1881 van mening was dat Westcott en Hort de goede weg insloegen. Wij lezen in het voorwoord voor de Revised Version (1881):

Textual criticism, as applied to the Greek New Testament, forms a special study of much intricacy and difficulty, and even now leaves room for considerable variety of opinion among competent critics.

Mensen als John W. Burgon en F. H. A. Scrivener waren minstens zo deskundig als Hort en meer dan Westcott. Zij verdedigden de Byzantijnse tekst als de belangrijkste of althans als een tekst die gelijkwaardig is aan andere typen. In hun 
voetspoor gingen mensen als E. Miller en H.C. Hoskier. Hun pleidooien mochten niet baten: het pleit was beslecht. Ook al heeft Hoskier (1914) de codex Vaticanus minutieus besproken én bekritiseerd, toch bleef B de kroongetuige voor de tekst, tot in Nestle-26 (nolens volens) toe.

Het weinig gebruikte en veelszins vergeten werk van deze tekstkritici kwam echter weer naar voren toen in de zeventigerjaren (meestal geheel onbekend met Burgon, Hoskier e.d.) verschillende mensen, onafhankelijk van elkaar botsten op het toenemend eclecticisme en door studie gingen twijfelen aan de juistheid van Horts vonnis over de Byzantijnse tekst. Hier is te noemen het werk van Harry A. Sturz (The Byzantine Text-Type and New Testament Textual Criticism (1984), gebaseerd op een Grace Theological Seminary dissertatie); Zane C. Hodges (diverse artikelen); W.N. Pickering (The Identity of the New Testament Text (1977), Rev. Edition 1980) en mijn kamper rectorale rede in 1975 over "De tekst van het Nieuwe Testament". Deze auteurs staan vij van het debat pro of contra de King James Version of Statenvertaling en zij vatten de lijn van Scrivener of Burgon weer op. Sam Moore, president van Thomas Nelson Publishers (de grootste bijbel-uitgeverij in de U.S.A.) bracht de mensën bijeen voor het verzorgen van een Grieks Nieuw Testament naar de meerderheid van de handschriften. Dat deze Majority-text op nogal wat punten afwijkt van de textus receptus, kan uit het apparaat volledig blijken. Zij wijkt echter op meer punten af van de Nestle-tekst. De beste illustratie voor het onafhankelijk karakter van deze uitgave is misschien wel te vinden in Romeinen $14 ; 16$. In de meeste handschriften komt de doxologie (16:25-27) na hoofdstuk 14. Tot nu toe hebben echter álle gedrukte uitgaven van het Griekse Nieuwe Testament de doxologie na hoofdstuk 16 geplaatst: er is dan ook geen enkele nieuwere vertaling (Reformatie en daarna) waarin zij na hoofdstuk 14 staat. Voor het eerst in de Majority-edition vindt men na Romeinen 14:23 ook nog 14:24-26 terwijl hoofdstuk 16 eindigt met vers 24. Dat ook het comma Johanneum niet is opgenomen, spreekt vanzelf.

De Majority-editie is een voorlopige. $\mathrm{Zij}$ is gebaseerd op de gegevens die Von Soden over de lezingen in de diverse handschriften-groepen biedt. Deze wat ruwe vaststelling behoeft nadere verfijning op grond van collatie van vele minuskels (evt. steekproefsgewijs). Het is echter onjuist om Von Soden een hoogst inaccurate editie te noemen voor wat het apparaat betreft: Maurice A. Robinson (1977) heeft aangetoond dat deze hetze tegen Von Soden (en zo ook tegen de basis van de Majority-editie) ongegrond is. Deze voorlopige editie biedt een redelijk werkmateriaal in een tijd dat de discussie nog volop gevoerd moet worden.

Duidelijke discussies zijn inmiddels gevoerd in Journal of the Evangelical Theological Society (Fee, 1978a; Fee, 1978b; Hodges, 1978a; Hodges, 1978b; Pickering, 1978) en in Calvin Theological Journal (Bandstra, 1981 en 1982, Van Bruggen, 1982).

Hodges argumenteert sterk vanuit de statistische waarschijnlijkheid (de juiste lezing zal zich altijd meer verbreiden dan de deviaties ervan). Als kritiek hierop 
is uitgebracht dat dit alleen telt bij een gelijkmatig verlopende traditie. Open vraag blijft dan of aangetoond kan worden dat de Byzantijnse tekst moet worden toegeschreven aan een bewuste ingreep op de traditie.

De bewering dat hier een Luciaanse recensie zou hebben ingewerkt wordt nog in het boek van Kurt en Barbara Aland staande gehouden, maar is stellig te ontkennen (Van Bruggen, 1976).

De interne argumenten tegen de Byzantijnse tekst betroffen vooral het voorkomen van conflate readings. Pickering (1980) toont echter in de tweede druk van zijn boek aan dat deze lezingen niet specifiek zijn voor het Byzantijnse type.

Door Robinson (1982) is inmiddels voor Openbaring aangetoond dat de gangbare gedachten over een proces van tekstbederf via scribal habits niet kloppen op de feiten.

Een onderzoek naar de 'harmoniserende lezingen' als kenmerkend voor de Byzantijnse tekst is verricht door W.F. Wisselink (1989). Zijn conclusie luidt:

Wanneer een variant bij vergelijking met andere lezingen 'assimilerend' genoemd kan worden, zegt dit niets over de ouderdom van deze variant noch over het tekst-type waarbinnen zij voorkomt (Wisselink, 1989:92).

Een witte vlek blijft het kerkvader-getuigenis. Burgon heeft in vele folianten zijn minutieuze onderzoek van de patristische citaten laten inbinden: het ligt onuitgeefbaar in het British Museum. Misschien hemeemt eens iemand dit onderzoek?

In 1991 verscheen een andere editie van de Byzantijnse tekst, namelijk The New Testament in the Original Greek according to the Byzantine/Majority Textform (Robinson \& Pierpont). De uitgevers schrijven: "They advocate a 'Byzantine-priority' rather than a solely 'Majority Text' hypothesis" (p. xli). Deze tekst stemt in opvallend grote mate overeen met die van Hodges en Farstad, maar wijkt er in belangrijke mate van af inzake de Pericope Adulterae en het boek Openbaring. Dit is niet zo vreemd, omdat Hodges juist in deze gedeelten een andere (genealogische) methode van tekstvaststelling had gevolgd. Deze editie van Robinson en Pierpont mist echter een kritisch apparaat.

Het pleidooi voor de oude tekst wordt weer gevoerd op basis van de feiten die wetenschappelijk verwerkt moeten worden. Een ernstige mate van tegenstand ondervindt dit pleidooi door de voorwetenschappelijke onderstelling van velen dat het Nieuwe Testament niet kan zijn gegeven als een directe goddelijke openbaring, maar eerst langzaam is gegroeid uit een veelheid van tradities en briefverzamelingen. Wanneer de variatie aan het begin stond, is de éne oude tekst altijd het eindstation. Maar wanneer de éne, door God geopenbaarde, tekst aan het begin stond, is het zoeken daarnaar geen onbegonnen werk. Bovendien neemt 
de kans dan toe dat deze oorspronkelijke tekst door een proces van tekstverandering heen is bewaard gebleven en hersteld. Niemand moet voor de Byzantijnse tekst kiezen op geloofsgronden, maar helaas kiezen velen wel bij voorbaat tegen deze tekst vanwege een vooroordeel. Er zou reeds veel zijn gewonnen wanneer men in het wetenschappelijk onderzoek rekening hield met de mógelijkheid dat het Nieuwe Testament een gegèven boek is en geen eindresultaat van een evolutie in het christendom.

\section{Hoor en wederhoor}

Een belangrijke winst van de laatste jaren is, dat iedereen die dat wil, nu in de gelegenheid is om de modeme compromistekst van een comité en de meerderheidstekst van de handschriften met elkaar te vergelijken.

Dit kan reeds binnen Nestle-26. Het siglum (gothische) $M$ bevat in ieder geval de Byzantijnse tekst en voorts ook nog alle niet vermelde ständige Zeugen. Echter: Aland vermeldt niet alle varianten en daarom-is zijn apparaat maar ten dele geschikt om de Byzantijnse tekst te leren kennen.

Beter is het dan om gebruik te maken van de editie van Hodges en Farstad. Hierin vindt men naast het apparaat waarin de variaties binnen de meerderheidstekst worden genoteerd ook nog een apparaat waarin de resterende verschillen met de Nestle-tekst zijn aangegeven. Daarom werkt het beter, wanneer men vanuit deze editie de meerderheidstekst leest en dan de verschillen met Nestle bestudeert.

Er zou veel gewonnen zijn wanneer men de verbannen tekst weer leerde kénnen. Onbekend maakt onbemind!

We moeten het belang van deze vergelijking niet overschatten én niet onderwaarderen.

Het zou een overschatting zijn wanneer men meende dat theologische verschillen gepaard gaan met de keuze tussen deze twee edities. Mensen uit het KJV-front wijzen graag op varianten in Nestle die docetisch of anti-christologisch zijn. Men kan dit echter ook in omgekeerde richting doen. De grondfout is dat men selecticf en incidenteel vergelijkt en op basis van zo 'n selectie waarde-oordelen geeft over het geheel.

Zo schrijft Petzer (1990:216) dat in Matteüs 24:36 de woorden oưó̀ ó viós "in sommige manuskripte" (lees: "in vrijwel alle manuscripten"!) ontbreken in een poging "om Jesus se godheid (alwetendheid) te beskerm". Breder bespreekt hij deze tekst op p. 235-236. Deze bespreking is een voorbeeld van de bevooroordeelheid van vele modeme tekstcritici. Vanwege hun allergie voor hamonisaties zou het voor de laand liggen, de toevoeging van de woorden vióś ó viós in Matteüs te beschouwen als een harmonisatie aan 
Marcus 13:32 waar deze woorden wel in vrijwel alle handschriften voorkomen. De harmonisatie zou echter ten nadele zijn van de niet-Byzantijnse tekst en nu wordt een andere redenering opgezet - een redenering die volstrekt niet teksthistorisch is. Petzer neemt de bijbelkritische stelling over dat de auteur van Matteüs een bewerker is van Marcus. Vervolgens stelt hij dat het vreemd zou zijn wanneer de schrijver van Matteüs de tekst van Marcus 13:32 letterlijk zou hebben overgenomen zonder de drie omstreden woorden. De weglating moet dus van latere datum zijn en te wijten wezen aan een dogmatische ingreep in de tekst. Hier rijzen echter vragen: waarom zou het zo vreemd zijn dat de schrijver van Matteüs iets weglaat wanneer een dogmatische tendens voor zo 'n weglating kan worden aangenomen? En waarom lieten latere bewerkers van Matteüs de omstreden woorden wel staan in Marcus 13? De opmerking dat ook daar de woorden soms ontbreken, doet niet ter zake omdat dit een uitzondering betreft (ms. X en pc). Kortom: de niet harmoniserende Byzantijnse tekst wordt beschuldigd van een dogmatische weglating van een passage die men rustig liet staan in Marcus 13!

Het theologisch belang van varianten wordt snel overschat. Het is echter wel zo dat theologen bij hun werk het belang van een variant zullen ontdekken. Bijvoorbeeld wanneer bij Matteüs 18 de vraag rijst of men onder vier ogen moet vermanen bij elke zonde of alleen wanneer een broeder "tegen u" heeft gezondigd. De meeste handschriften lezen wél de woorden "tegen u". Zoiets doet zich ook voor bij het breken van het avondmaalsbrood als liturgisch gebaar: dit kan alleen gebaseerd worden op de meerderheidstekst van 1 Korintiërs 11:24 (“dat voor u gebroken wordt" i.p.v. "dat voor u gegeven wordt": zie voor deze tekst ook Van Lopik, 1991).

Mijn praktische advies zou zijn, zich in zulke gevallen tot andere teksten of argumenten te wenden. Het is gevaarlijk, wanneer men tekstkritische beslissingen laat afhangen van theologische voorkeur voor een variant. Het is bovendien heel gezond voor theologen wanneer zij zich niet teveel op woordjes en stukjes van zinnen vastbijten, maar gehele teksten lezen en die als uitgangspunt nemen.

Toch moet men het belang van een keuze tussen de twee edities niet onderschatten. Een keuze moet gemaakt word wanneer de bijbel vertaald wordt en wanneer een exegeet een tekst geheel wil uitleggen. De Guidelines for Interconfessional Cooperation in Translating the Bible (in 1968 opgesteld en in 1987 bijgesteld door de Wereldbond van bijbelgenootschappen en het Secretariaat voor de eenheid van de christenen) spreken zich nadrukkelijk uit voor de 26 ste in combinatie met de 25 ste druk van Nestle, terwijl Byzantijnse lezingen in voetnoten vermeld kunnen worden. Wie vertaalt en exegetiseert, moet kiezen of moet zich op zijn minst bewust zijn van de implicaties der varianten. 
Ik pleit dan ook voor het weer luisteren naar de verbannen tekst: klinkt hier de stem die ons uit het moeras van de varianten kan trekken?

\section{Anti-propaganda tegen de stem van een balling}

Tot dit luisteren zijn veel mensen niet zo geneigd. Er heerst nog steeds een sfeer van ongeloofwaardigheid rond de Byzantijnse tekst. Deze is het blijvend gevolg van een eeuw anti-propaganda. Ik wil enkele leuzen van die propaganda daarom kort toetsen.

\section{1 'De Byzantijnse tekst kan niet goed zijn omdat er zo 'n type niet is in de eerste eeuwen'}

Hiertegen valt in te brengen dat we voor de eerste eeuwen alleen beschikken over materiaal uit Egypte en dat we totaal niet weten hoe het teksttype was te Antiochië, Efeze of Rome. De Byzantijnse tekst moet ergens vandaan komen (zie onder): het is heel goed mogelijk dat daarin de teksttraditie van Antiochie is doorgestroomd.

Bovendien is het opvallend dat veel zogenaamde Byzantijnse lezingen wel voorkomen in de eerste eeuwen. Hoe kunnen lezingen voorkomen voordat een tekst geboren is?

Dit alles zou niet gelden wanneer de Byzantijnse tekst aantoonbaar het resultaat van samenvoeging en redactie was. Daarvan is echter geen spoor. Het is ook (historisch gezien) uitgesloten dat men in de derde of vierde eeuw een tekst zou zijn gaan maken zoals het UBS-comite dit in de 20ste eeuw deed. In de derde/ vierde eeuw domineert reeds de conserverende mentaliteit (verg. de voorbeelden bij Metzger (1992:195-196) over een kanttekening in de Vaticanus ["laat het oude staan!"] en een conflict op een concilie over de vervanging van een verouderd woord bij het citeren van de bijbel).

Petzer (1990:76-78) meent dat er in de vierde eeuw een standaardisering van de Griekse tekst moet hebben plaatsgevonden, al ontbreekt elk spoor van opdracht of kerkelijk besluit. De Byzantijnse tekst was er immers eerder nog niet! Hij trekt een parallel met het werk aan de Septuagint en de Syriaca. Petzer zegt dat de Byzantijnse tekst een tekst is "wat nie in ouer bronne gevind word nie". Vanwege het partiële karakter van de bronnen die ons voor de eerste eeuwen op dit punt ter beschikking staan, is het echter niet verantwoord op deze constatering met betrekking tot het ons bekende een conclusie te bouwen voor het vele ons onbekende. 


\section{2 'De Byzantijnse tekst komt niet voor in oude manuscripten en die zijn altijd waardevoller'}

Hier geldt opnieuw dat we oude manuscripten (papyri) alleen in Egypte aantreffen. En juist hier is veel divergentie. Aland tracht die wel te bezweren door binnen de papyri weer diverse typen te onderscheiden (zodat alleen een Standardtext overblijft), maar dit versterkt de geloofwaardigheid van de oude documenten als zodanig niet.

Er zijn ook kanttekeningen te maken.

- Aanvankelijk was de Griekse tekst ook de gelezen tekst: de handschriften waren daarom onderworpen aan moderniseringsprocessen die gepaard gaan met actueel in gebruik zijnde bijbels en liturgieboeken. Pas na enkele eeuwen ziet men dat het nodig is om de standaard vast te houden opdat men door al die kleine aanpassingen niet te ver van huis raakt. Daarom zijn handschriften uit latere eeuwen niet per definitie minder. Het is eerder te verwachten dat zij als resultaat van een terugkeerbeweging beter zijn dan die uit de tweede en derde eeuw. De 20ste-eeuwse uitgave van de Statenvertaling in het Nederlands is beter dan de edities uit de tijd toen drukkers haar steeds adapteerden (18de, 19de eeuw)!

- Te rekenen is met de translitteratie in de 8ste eeuw: de oude boeken werden in minuskelschrift overgezet en zo 'n minuskel bevat juist de oude en gerespecteerde tekst!

\section{3 'Bij de kerkvaders vinden we aanvankelijk geen Byzantijns teksttype'}

Dit is maar ten dele na te gaan, omdat we juist weinig Griekse kerkvaders hebben uit de eerste eeuwen en omdat de citaten meestal nogal vrij zijn weergegeven. Toch is het opvallend dat we bij Didymus de Blinde en zeker bij Chrysostomus al veel Byzantijnse lezingen aantreffen.

Een klein voorbeeld hierbij. In Lucas 10:1 is de lezing zeventig niet aan te treffen in de oudere manuscripten. Toch bestaat reeds in Tertullianus' tijd een standaard vergelijking tussen de 12 met de 70 apostelen en de twaalf waterbronnen met de 70 palmbomen in Elim.

Een ander voorbeeld: zorgvuldig onderzoek leert dat het langere slot van Marcus 16:9-20 bij verreweg de meeste kerkvaders al bekend was (zie Van Bruggen, 1988). 


\section{4 'Het karakter van de Byzantijnse tekst is inferieur'}

Hierboven werd reeds opgemerkt dat dit weerlegd is voor de zogenaamde conflate readings en de assimilatie.

Wat betreft het zogenaamde expliciete karakter van de Byzantijnse tekst geldt het volgende. Het betreft hier alleen elementen die gemist kunnen worden (zoals

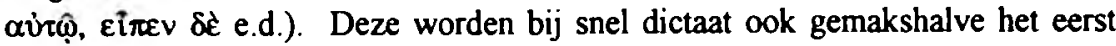
overgeslagen. Het ligt meer voor de hand dat de niet-Byzantijnse tekst soms geleden heeft onder deze dictaatinkortingen. Het gaat namelijk heel opvallend om een niet-systematisch voorkomend verschijnsel. De Byzantijnse tekst mist elke systematiek in het expliciet zijn en daarom is redactie hier minder waarschijnhjk dan echtheid die elders verloren ging.

\section{Een eigen stemgeluid!}

Er valt ook iets te zeggen ten voordele van de Byzantijnse tekst.

\subsection{Verdeeldheid van de zogenaamde Egyptische tekst}

De zogenaamde Egyptische tekst is innerlijk verdeeld: de handschriften zijn meestal minstens partieel Byzantijns (A). Zelfs het beste Egyptische manuscript kan niet integraal gevolgd worden (B). De papyri zijn verdeeld en moeten via Aland tot een Standard-tekst gereduceerd worden waarvoor geen andere criteria zijn dan de Aland-editie!

Daarnaast zijn er echter bijna altijd niet-Byzantijnse medegetuigen voor een Byzantijnse lezing! Daarom is de Byzantijnse tekst de beste als uitgangspunt voor collatie (zie de Lucas-editie van IGNTP). Dit wijst erop dat de variatie rond de Byzantijnse tekst is te beschrijven als deviatie van een centrale, oudere tekst. Die deviatie is niet systematisch en is veroorzaakt door een reeks (meestal triviale) factoren, waarvan de voornaamste is het 'bijwerken' van de kerkelijke leesbijbel in de eerste periode.

\subsection{Onverdachte elementen in de Byzantijnse tekst}

De Byzantijnse tekst heeft onverdachte elementen in zich die wel echt moeten zijn en die een eigen (ons onbekende) oude brontekst aantonen.

Ik wil eindigen met hiervan enkele voorbeelden te noemen uit het evangelie naar Lucas (vergelijk Van Bruggen, 1993).

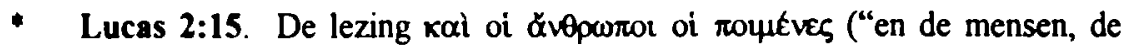
herders") kan gemakkelijk door homoioteleuton vereenvoudigd zijn tot "de 
herders" (zonder "en de mensen"), omdat de uitgang -or een groot aantal

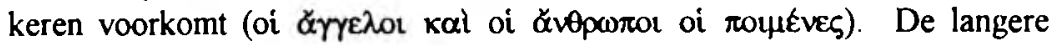
lezing past goed bij Lucas' stijl. Het is moeilijk in te zien waarom men ooit de woorden "en de mensen" zou hebben toegevoegd. Doorslaggevend is, dat verreweg de meeste handschriften de langere lezing bewaarden. Hoe gemakkelijk de woorden 'en de mensen' wegvallen, blijkt uit de Statenvertaling, waar men ze niet vindt, terwijl uit de kanttekeningen blijkt dat de vertalers ze wel lazen in hun Griekse tekst!

* Lucas 2:33. De meeste handschriften lezen "Jozef en zijn moeder". In een aantal handschriften is deze uitdrukking, die niet zo correct geformuleerd is (gaat het om Jozefs moeder?), gecorrigeerd tot "zijn vader en moeder". Zo is in 2:43 de woordgroep "Jozef en zijn moeder" gecorrigeerd tot "zijn ouders". Deze correcties worden in nieuwere vertalingen als origineel beschouwd. Het argument is, dat men ter bescherming van de leer dat Jezus zonder Jozefs toedoen is verwekt, uitdrukkingen als "zijn vader en moeder" of "zijn ouders" zou hebben vervangen door een nadrukkelijk onderscheidende formulering: "Jozef en zijn moeder". Petzer (1990) behandelt dit vers op twee plaatsen: op p. 62-63 (waar abusievelijk 6:33 staat [zo ook in het

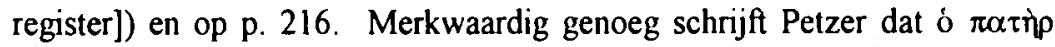
av่ov "in sommige manuskripte" (p. 62) is vervangen door Twoń $\varphi$. De

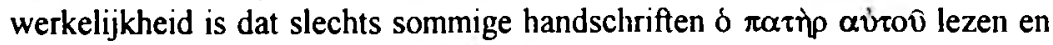

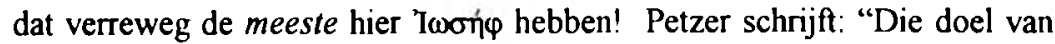
die verandering is waarskynlik om die maagdelike geboorte te beskerm en te vermy dat Josef as die vader van Jesus aangedui word" (p. 63 verg. 216). Dit argument blijkt een foute hypothese: vrijwel alle handschriften laten in 2,27.41 de woorden "zijn ouders" staan; en hetzelfde geldt van 2:48 waar Maria (NB!) spreekt tot Jezus over "uw vader en ik". Het is niet aan te nemen dat men een zogenaamd aanstootgevende lezing slechts in twee gevallen wegnam en verder rustig liet staan. Anderzijds blijken de varianten precies de enige twee keer te betreffen dat Lucas de voor sommigen wat incorrecte formulering "Jozef en zijn moeder" gebruikt. De weergave van de oudere vertalingen verdient op deze twee punten $(2,33.43)$ de voorkeur boven nieuwere vertalingen.

* Lucas 6:1. In 6:1 lezen we volgens de meerderheid van de handschriften

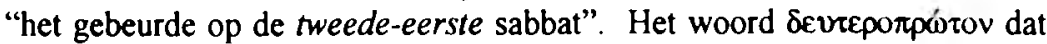
in de minderheid van de handschriften ontbreekt, is moeilijk te verklaren. De grote spreiding van deze lezing maakt het echter onwaarschijnlijk, dat ze door misverstand zou zijn ontstaan en is af te doen als een zinloze vergissing (Skeat, 1988) of dat ze zou zijn ingevoegd door een schrijver die de tweede sabbatsperikoop tot de eerste wilde maken (Buchanan \& Wolfe, 1978) of dat we hier een samensmelting hebben van een verbetering van een glosse met de oorspronkelijke glosse (Metzger, 1971:139) ad locum: 'eerste' sabbat ten opzichte van 6:6 en 'tweede' ten opzichte van 4:31). Aannemelijker zijn 
hypothesen, die uitgaan van de authenticiteit van het woord. Zo denkt bijvoorbeeld Mezger (1976) dat we het moeten scheiden in twee woorden en opvatten als "op de tweede sabbat in de eerste (maand)" zodat hier een precieze datering in de maand Nisan is bedoeld. Vanwege gebrek aan vergelijkingsmateriaal blijft het echter moeilijk om een oordeel te geven over deze en andere verklaringen.

- Lucas 24:43. In een beperkt aantal handschriften en in veel nieuwere vertalingen ontbreken de woorden "en een brokje honigraat". Het is onvoorstelbaar dat men dit zou hebben toegevoegd (om welke reden?) of dat het een ingeslopen glosse zou zijn (waarbij?). Het is echter heel goed mogelijk (verg. Kilpatrick, 1986) dat de weglating van 21 letters het gevolg is

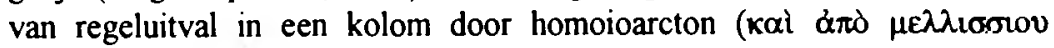

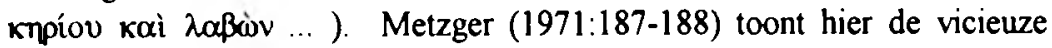
cirkel van veel modeme tekstvaststelling.

- Hij verzwijgt dat het een homoioarcton kan zijn.

- Vervolgens zegt hij dat het een interpolatie moet zijn "for it is not likely that they would have fallen out of so many of the best representatives of the earlier text-types" (Metzger, 1971:188). In plaats van nu eens aan te nemen dat de Byzantijnse lezing ouder zou kunnen zijn, blijft het dogma van de oudere tekst-types onaangevochten. En de handschriften die eenmaal "the best" zijn, kunnen daarna blijkbaar geen kwaad meer doen.

- Het comité moet dan wel tot een heel vreemde verklaring komen: de honig zou zijn toegevoegd omdat delen van de oude kerk het gebruikten bij de viering van de eucharistie en bij de doopliturgie. Men heeft de toevoeging dus gedaan om "scriptural sanction for liturgical practice" (Metzger, 1971:188) te hebben. Het gaat in Lucas 24:42 echter helemaal niet over de eucharistie, wanneer men aan Jezus een stuk gebraden vis aanreikt. Waarom hebben delen van de oude kerk die hier de honig toevoegden om hun liturgie te onderbouwen, die liturgie dan ook niet verrijkt met vis bij de eucharistie of vissen in het doopwater?

De honig die de leerlingen na Pasen aan Jezus gaven, is per abuis zoekgeraakt in een aantal handschriften, maar zuinig bewaard in de Byzantijnse traditie. De slotsom van mijn lezing is daarom kort en goed: Proef de honig van een verbannen tekst, mijn zoon, en word wijs!

\section{Geciteerde literatuur}

ALAND, K \& ALAND, B. 1982. Der Text des Neuen Testaments Einfürung in die wissenschaflichen Ausgaben sowie in Theorie und Praxis der modernen Textkritik Stuttgart : Deutsche Bibelgesellschaf 
BANDSTRA, A J. 1981. The Original Form of the Lord's Prayer. Calvin Theological Journal, 16:15-37.

BANDSTRA, A.J. 1982. The Lord's Prayer and Textual Criticism: A Response. Calvin Theological Journal, 17:88-97.

BUCHANAN, G.W. \& WOLFE, CHR. 1978. The Second-First Sabbath (Luke 6:1). Journal of Biblical Literature, 97:259-262

FEE, G.D 1978a Modern Textual Criticism and the Revival of the Textus Receptus Journal of the Evangelical Theological Society, 21:19-33

FEE, G.D. 1978b. Modern Textual Criticism and the Majority Text: A Rejoinder. Journal of the Evangelical Theological Society, $21: 157-160$.

FULLER, DAVID OTIS. 1971. Which Bible? Second Edition Grand Rapids: Grand Rapids International Publications.

HODGES, Z.C. 1978a. Modem Textual Criticism and the Majority Text: A Response Journal of the Evangelical Theological Society, 21:143-155.

HODGES, Z.C. 1978b. Modern Textual Criticism and the Majority Text: A Surrejoinder. Journal of the Evangelical Theological Society, 21:161-164.

HODGES, ZANE C. \& FARSTAD, ARTHUR I 1982. The Greek New Testament according to the Majority Text (edited by Zane C. Hodges and Arthur L. Farstad) Nashville : Thomas Nelson Publishers. (Tweede druk 1985.)

HOSKIER, H.C. 1914 Codex B and Its Allies. I-II. London : Bernard Quaritch.

KILPATRICK, G.D. 1986. Luke 24:42-43. Novum Testamentum, 28:306-308.

LETIS, T.H. P. ed 1987. The Majority Text: Essays and Reviews in the Continuing Debate. Grand Rapids : Institute for Biblical Textual Studies

METZGER, E. 1976 Le sabbat "second-premier" de Luc Theologische Zeitschrift, 32.138143.

METZGER, B M. 1992. The Text of the New Testament Its Transmission, Corruption and Restoration. Third, Enlarged Edition Oxford : Oxford University Press.

MEZGER, B M. 197I. A Textual Commentary on the Greek New Testament London : United Bible Societies

PETZER, KOBUS (= J H. PETZER) 1990 Die teks van die Nuwe Testament 'n Inleiding in die basiese aspekte van die teorie en praktyk van die tekskritiek van die Nuwe Testament. (Hervormde Teologiese Studies, suppl 2). Pretoria : Univ, van Pretoria

PETZER, J.H. 1991 Eclecticism and the Text of the New Testament (In Hartin, PJ \& Petzer, J.H. eds. Text \& Interpretation. New Approaches in the Criticism of the New Testament. (New Testament Tools and Studies 15). Leiden : Brill. p. 47-62.)

PICKERING, W N. 1978 'Queen Anne 'and All That: A Response Journal of the Evangelical Theological Society, 21:165-167.

PICKERING, WN. 1980. The Identity of the New Testament Text Rev Edition. Nashville : Thomas Nelson Publishers.

RADL, W. 1988. Das Lukas-Evangelium (Ertrage der Forschung 261.) Darmstadt Wissenschaftliche Buchgesellschaft. p 12-13.

ROBINSON, MAURICE A. 1977. Von Soden's Folly: The Greek New Testament that Failed? Fort Worth : Southwestern Baptist Theological Seminary. (Scriptie.)

ROBINSON, MAURICE A. 1982. Scribal Habits among Manuscripts of the Apocalypse Fort Worth : Southwestern Baptist Theological Seminary (Scriptie.)

ROBINSON, MAURICE A \& PIERPONT, WILLIAM G. 1991. The New Testament in the Original Greek according to the Byzantine/Majority Textform. Atlanta : The Original Word Publishers

SKEAT, T.C. 1988. The 'Second-First' Sabbath (Luke 6:1). The Final Solution. Novum Testamentum, 30:103-106. 
STURZ, H.A. 1984. The Byzantine Text-type and New Testament Textual Criticism. Nashville : Thomas Nelson Publishers

VAN LOPIK, T. 1991. Tekstkritiek: telt het wegen of weegt het tellen? Nederlands Theologisch Tijdschrift, 45:101-106).

VAN BRUGGEN, J 1976. De tekst van het Nieuwe Testament. Groningen : Vuurbaak.

VAN BRUGGEN, J 1982. The Lord's Prayer and Textual Criticism. Calvin Theological Journal, 17:78-87.

VAN BRUGGEN, J. 1988. Behoort het gedeelte 16,9-20 bij het evangelie naar Marcus? (In Van Bruggen J. Marcus. Het evangelie volgens Petrus. (Commentaar op het Nieuwe Testament. Derde Serie. Afdeling Evangelien.) Kampen : Kok pp. 413-418.)

VAN BRUGGEN, J 1993. Lucas. Het evangelie als voorgeschiedenis (Commentaar op het Nieuwe Testament. Derde Serie Afdeling Evangelien.) Kampen : Kok

WISSELINK, W.F. 1989. Assimilation as a Criterion for the Establishment of the Text. A Comparative Study on the Basis of Passages from Matthew, Mark and Luke Kampen : Kok. 
